\title{
Kwaliteitsregistraties: van meten naar verbeteren
}

\author{
Ingrid E. C. van Es ${ }^{1}$ Sylvia Shackleton-Dijkstra ${ }^{1}$
}

Published online: 14 October 2016

(C) The Author(s) 2016. This article is available at SpringerLink with Open Access.

Samenvatting Inzicht in kwaliteit is essentieel om te kunnen sturen op kwalitatief goede en doelmatige zorg. Tal van gedreven artsen hebben kwaliteitsregistraties opgezet om te kunnen benchmarken en daarmee hun kwaliteit van zorg voor de patiënt te verbeteren.

Trefwoorden oncologie f functionele urologie kinderurologie $\cdot$ blaas $\cdot$ prostaat $\cdot$ nier $\cdot$ andrologie $\cdot$ urolithiasis

\section{Quality registry: from measurement to improvement}

\begin{abstract}
Goalsetting for qualitatively good and efficient care is only possible on the basis of insights into the quality of care. Many enthusiastic doctors designed quality registers to enable benchmarking with the aim to improve their quality of care for patients.
\end{abstract}

Keywords oncology functional urology pediatric urology $\cdot$ bladder $\cdot$ prostate $\cdot$ kidney $\cdot$ andrology $\cdot$ urolithiasis

\section{Doel van registreren}

Kwaliteitsregistraties zijn opgezet om kwaliteitsgegevens onderling te kunnen vergelijken, om van te leren, patiënten-

drs. Ingrid E. C. van Es

i.van.es@nvz-ziekenhuizen.nl

1 Nederlandse Vereniging van Ziekenhuizen, Utrecht, Nederland uitkomsten te verbeteren en variaties tussen ziekenhuizen te verkleinen. Dit proces vindt plaats in een veilige omgeving, waarin artsen en bestuurders, als onderdeel van de clinical governance, data en uitkomsten kunnen bespreken. Hierdoor zijn mooie resultaten bereikt, waaronder:

- Toediening van trombolytica binnen een uur na het optreden van een CVA wordt nu toegepast bij $84 \%$ van de patiënten, een stijging van $19 \%$ in drie jaar [1].

- Na een borstkankeroperatie blijft tumorweefsel achter bij $11 \%$ van de patiënten, een afname van $10 \%$ in het eerste jaar dat de indicator hiervoor is opgenomen in de basisset van de IGZ.

- Het optreden van doorligwonden is met $80 \%$ afgenomen in acht jaar tijd.

- Chirurgen drongen in vier jaar tijd de sterfte na een pancreaticoduodenectomie terug met $50 \%$.

- Tussen 2009 en 2014 is er een afname van $56 \%$ gerealiseerd van sterfte na darmkankeroperaties (van 5,2\% naar $2,3 \%$ ).

- Tussen 2011 en 2014 is een afname van $47 \%$ gerealiseerd in de sterfte na maagkankeroperaties (van $8,5 \%$ naar $4,5 \%$ ) [2].

\section{Keerzijde van het succes}

Het succes van kwaliteitsregistraties kent ook een keerzijde en de praktijk is weerbarstiger dan bovenstaande doet vermoeden. Het aantal kwaliteitsregistraties is de afgelopen jaren enorm gegroeid naar 150-200 zorginhoudelijke registraties [3]. Het registratielandschap is hierdoor versnipperd en registraties verschillen in opzet, inhoud, scope en aanpak. Om een aantal voorbeelden te noemen: 
- Registraties zijn mono- of multidisciplinair en dus gericht op een ingreep, de diagnostiek en behandeling van een aandoening of een afdeling van het ziekenhuis.

- Registraties kunnen primair zijn opgericht met de doelstelling kwaliteitsverbetering of kunnen een bredere doelstelling hebben, zoals complicatieregistraties, kosteneffectiviteitsmetingen of wetenschappelijk onderzoek.

- Registraties kunnen het registreren en benchmarken faciliteren, maar bevatten soms ook extra dienstverlening, zoals visitaties en accreditaties.

- Registraties kunnen medische uitkomsten meten (klinische registratie door artsen) en/of patiëntuitkomsten en -ervaringen (PROMs en PREMs vragenlijsten voor patiënten).

\section{Handmatige vastlegging}

De meeste gegevens voor kwaliteitsregistraties zijn nog niet gestandaardiseerd te onttrekken uit het Elektronisch Patiënten Dossier (EPD) en moeten vaak handmatig worden vastgelegd, naast het EPD. Het invoeren van de vaak grote datasets in de kwaliteitsregistraties vraagt een grote inspanning van artsen en ondersteunend personeel, waardoor het draagvlak om te registreren afneemt. Daarnaast is de betrouwbaarheid van een registratie naast het EPD kleiner, doordat artsen steeds alert moeten zijn dat alle patiënten ook daadwerkelijk tijdig en volledig in de kwaliteitsregistratie terechtkomen.

\section{Kwaliteitsregistraties en transparantie}

Daarnaast zien we dat de indicatoren uit de kwaliteitsregistraties steeds meer gebruikt worden voor transparantie. Dit is een logische gedachte. Hierdoor kan gebruik worden gemaakt van data en indicatoren die artsen waardevol en betekenisvol vinden en die toch al worden vastgelegd. Ook draagt een dergelijke toepassing van data bij aan het voorkomen van dubbele registratie en wordt bovendien het woud van indicatoren dat aan instanties moet worden aangeleverd, ermee gestroomlijnd. Maar, het gebruik van kwaliteitsregistraties voor transparantie heeft een keerzijde. Door gedwongen winkelnering vanuit de inkoopvoorwaarden van zorgverzekeraars, door eisen van wetenschappelijke verenigingen, door keurmerken of door opname van indicatoren uit de kwaliteitsregistraties op de Transparantiekalender of in de IGZ-basisset wordt deelname afgedwongen. Voor registratieorganisaties is deze dwang een legitimering van hun bestaansrecht, waarmee de prikkel vervalt om aan doelmatigheid te werken.
Daarnaast zijn de indicatoren uit kwaliteitsregistraties inmiddels erg belangrijk geworden voor met name zorgverzekeraars. Hierdoor zijn kwaliteitsregistraties niet langer een instrument om de kwaliteit van zorg te verbeteren, maar een verantwoordingsinstrument. De NVZ vindt dit een zorgelijke ontwikkeling: de oorspronkelijke goede intentie van kwaliteitsregistraties wordt hiermee tenietgedaan. Wij pleiten daarom voor een duidelijk onderscheid tussen een beperkte - hoeveelheid indicatoren die geschikt zijn voor transparantie, en indicatoren die geschikt zijn voor leren en verbeteren.

\section{Kosten van kwaliteitsmetingen}

KPMG Plexus heeft eind 2015 onderzoek verricht naar de kosten van kwaliteitsmetingen en komt uit op een jaarlijks bedrag van maximaal 80 miljoen euro [4]. Dit bedrag betaalden ziekenhuizen in 2014 voor kwaliteitsmetingen, waarvan het grootste deel voor kwaliteitsregistraties. Deze kosten zijn opgebouwd uit directe kosten (betalingen voor deelname aan de registratie), maar vooral ook uit personeelskosten. In een ziekenhuis werkt tussen 6,2 en 8,5 fte aan zorgprofessionals aan het invoeren, controleren en aanleveren van alle data ten behoeve van de kwaliteitsregistraties. Met de groei van het aantal kwaliteitsregistraties zullen deze inzet en kosten verder toenemen. Wij merken nu al dat het draagvlak voor kwaliteitsregistraties minder wordt bij artsen en raden van bestuur van ziekenhuizen. Als deze trend zich doorzet, zullen kwaliteitsregistraties zichzelf uiteindelijk de das om doen.

\section{Terug naar de essentie}

Moeten ziekenhuizen dan stoppen met het meten van kwaliteit? Nee, zeker niet. We moeten terug naar de essentie, namelijk: het verbeteren van de kwaliteit van zorg. Dus, weer terug naar verbeterinstrument in plaats van verantwoordingsinstrument. Daarnaast is het van belang dat de kosten van kwaliteitsregistraties en de registratielasten in verhouding staan tot de kwaliteitsverbetering. Hiervoor is een aantal veranderingen nodig:

\section{Gelijkgerichtheid van professional en bestuurder: gezamenlijke agenda}

Het initiatief voor kwaliteitsregistraties ligt veelal bij artsen en wetenschappelijke verenigingen. Artsen zien de goede voorbeelden van collega's en willen graag de kwaliteit van zorg voor hun eigen patiëntencategorie verbeteren. Vervolgens wordt met subsidie een kwaliteitsregistratie gestart, waarbij wordt verwacht dat na afloop van de subsidie de 
rekening wordt betaald door de ziekenhuizen. Het niet zonder meer continueren van de financiering leidt tot onvrede bij wetenschappelijke verenigingen, maar ook bij ziekenhuizen. Zeker als de toegevoegde waarde van een kwaliteitsregistratie onvoldoende helder is of prijs en kwaliteit niet in verhouding lijken.

Het venijn zit echter in de start. Er is een gezamenlijke en inhoudelijke kwaliteitsagenda nodig om te bepalen voor welke aandoeningen of onderwerpen kwaliteitsregistraties zouden moeten worden ontwikkeld. Het 'Voorwaardenkader kwaliteitsregistraties Medisch Specialistische Zorg' biedt hiervoor voldoende handvatten. In dit kader - dat is ontwikkeld door FMS, NVZ, NFU, NPCF, ZN en ZKN en inhoudelijk grotendeels is overgenomen door het Zorginstituut, in de leidraad kwaliteitsregistraties - staan alle relevante criteria. De introductie van dit kader betekent niet dat lokale initiatieven van enthousiaste en gedreven artsen niet meer mogelijk zijn, maar wel dat landelijke opschaling op basis van gezamenlijke uitgangspunten moet geschieden.

\section{Financiering}

Pas als een kwaliteitsregistratie relevant is bevonden en voldoet aan de criteria voor kwaliteit, organisatie en bedrijfsvoering, kan worden gekeken naar de financiering. Op dit moment vindt financiering plaats via lokale onderhandeling tussen ziekenhuis en zorgverzekeraar. Het macrobudget kent echter een plafond. Dit betekent dat de kosten van kwaliteitsregistraties afgaan van het zorgbudget van een ziekenhuis, hetgeen - voor zowel artsen als registratiehouders - een prikkel zou moeten zijn om de opzet en doorontwikkeling van kwaliteitsregistraties zo doelmatig mogelijk aan te pakken. Door als ziekenhuizen gezamenlijk met medisch specialistische bedrijven lokaal afspraken te maken over (gezamenlijke) financiering van kwaliteitsregistraties, ontstaat meer gelijkgerichtheid. Op deze manier ontstaat ook een doelmatigheidsprikkel bij medisch specialisten om registratielast en -kosten te beperken.

Een ander alternatief is het instellen van een landelijk fonds voor kwaliteitsregistraties. Dit fonds kan publiek worden gefinancierd. Instellingen kunnen op basis van een toetsing door het 'Voorwaardenkader kwaliteitsregistraties' in aanmerking komen voor financiering. In beide gevallen geldt dat het macrokader beperkt is en zorgprofessionals samen met zorgaanbieders de prioriteiten moeten bepalen voor het verbeteren van de kwaliteit van zorg.

\section{Geen gedwongen winkelnering}

Deelname aan kwaliteitsregistraties wordt vaak verplicht gesteld door inkoopvoorwaarden van zorgverzekeraars. Ook het opnemen van kwaliteitsindicatoren uit kwaliteitsregistraties op de Transparantiekalender of in de IGZ- basisset leidt tot min of meer verplichte deelname aan kwaliteitsregistraties. In theorie bestaat de vrijheid en mogelijkheid om de indicatoren zelf, of op een andere wijze, aan te leveren. Zonder kwaliteitsregistratie is dat echter vrijwel ondoenlijk. Daarnaast wordt deelname van ziekenhuizen aan kwaliteitsregistraties via de indicatoren zelf uitgevraagd, wat gedwongen winkelnering met zich meebrengt. We zien dit bijvoorbeeld terug in de IGZ-basisset. Deze opzet kan leiden tot een gebrek aan mogelijkheden voor ziekenhuizen om in gesprek te gaan over de kosten van een kwaliteitsregistratie in relatie tot de geleverde kwaliteit, en er is geen sprake van een gezonde klant-leverancierrelatie en een markt. Er is nog een andere oorzaak voor het ontbreken van een markt. Om te kunnen benchmarken moet er bij voorkeur maar één kwaliteitsregistratie voor één onderwerp bestaan. Dit betekent dat kwaliteitsregistraties niet in handen van commerciële organisaties zouden moeten zijn.

\section{Herstructurering van het registratielandschap}

De bewerkersrol van kwaliteitsregistraties is versnipperd, waardoor ziekenhuizen via verschillende kanalen (deels overlappende) informatie moeten aanleveren. Ook is het voor kleinere databanken een uitdaging om aan de steeds strenger wordende privacywetgeving te voldoen. Deze versnippering veroorzaakt hoge kosten. Een oplossing die op dit moment wordt verkend, is het meer centraliseren van de bewerkersrol, zodat er één bewerker onder regie van zorgprofessionals en ziekenhuizen ontstaat en versnippering tegen wordt gegaan. Als er slechts één bewerker is, kunnen zorgprofessionals en ziekenhuizen daadwerkelijk regie voeren en hebben zij gezamenlijk zeggenschap over data. De bewerker krijgt te maken met veel vertrouwelijke ziekenhuisinformatie waar prudent mee moet worden omgegaan en heeft daarmee een maatschappelijke functie. De wetenschappelijke verenigingen blijven per aandoening verantwoordelijkheid voor inhoud, methodologische opzet en duiding van data uit de kwaliteitsregistraties. De inhoudelijke rol van artsen bij de kwaliteitsregistraties verandert hierdoor niet, alleen de bewerkersfunctie wordt gecentraliseerd. Deze transitie kan niet in één keer plaatsvinden, maar is een groeimodel voor de komende jaren.

\section{Vermindering van registratielast}

De huidige registratielast is hoog. Een half uur per patiënt is geen uitzondering. Dit staat niet meer in verhouding tot bijvoorbeeld een (operatieve) ingreep. Dat zal niemand ontkennen. Het antwoord voor het verlichten van de registratielast voor artsen is niet het inhuren van meer ondersteunend personeel om deze registraties in te vullen, maar is het gestandaardiseerd vastleggen van gegevens. Op dit 
moment worden in de ziekenhuizen, maar ook in de verschillende kwaliteitsregistraties andere definities gebruikt voor dezelfde gegevens. Dit betekent dat gegevens steeds opnieuw vastgelegd moeten worden voor een ander doel. Standaardisatie betekent niet dat hierdoor alle gegevens gestructureerd moeten worden vastgelegd en er geen ruimte meer is voor vrije tekst. Wel is het zo dat gegevens die meervoudig gebruikt kunnen worden voor uitwisseling met bijvoorbeeld kwaliteitsregistraties, gestandaardiseerd vastgelegd worden in het EPD.

Voor het gestandaardiseerd vastleggen van gegevens kunnen de zorginformatiebouwstenen uit registratie aan de bron gebruikt worden. Een zorginformatiebouwsteen beschrijft nauwkeurig wat er over een bepaald item van het zorgproces van de patiënt moet worden vastgelegd. De zorginformatiebouwstenen zijn opgesteld op basis van bestaande nationale en internationale standaarden. Als ziekenhuizen gegevens gestandaardiseerd kunnen vastleggen (of afleiden), kunnen kwaliteitsregistraties hun dataset volgens dezelfde zorginformatiebouwstenen opbouwen. De gegevens die worden vastgelegd in het kader van het primaire proces in het EPD, vormen daarbij het uitgangspunt. Dit is een omvangrijke verandering in de ziekenhuizen en een meerjarentraject. In de tussentijd kunnen kwaliteitsregistraties al stappen maken door de (delen van de) dataset op te bouwen uit zorginformatiebouwstenen en de dataset zo beperkt mogelijk te houden.

\section{Van meten naar verbeteren}

Alle registratielast, aanleververplichtingen en discussies over zeggenschap en financiën leiden af van de stap die artsen wilden maken toen de eerste kwaliteitsregistraties werden ontwikkeld, namelijk de stap van 'meten is weten' naar 'weten is verbeteren'. Alleen zo kan het klimaat worden gecreëerd om in ziekenhuizen en in de netwerken waarin ziekenhuizen opereren, daadwerkelijk te komen tot een continue verbetering van de kwaliteit van zorg.

\section{Conclusie}

Het meten van kwaliteit loont, mits kwaliteitsregistraties worden opgezet vanuit een verbeterdoelstelling, met een efficiënt en doelmatig registratielandschap. Daarin hebben zorgprofessionals en ziekenhuizen de regie over de informatie en heeft de buitenwereld vertrouwen dat zorgprofessionals en bestuurders graag inzicht geven in de kwaliteit van zorg.

Open Access This article is distributed under the terms of the Creative Commons Attribution 4.0 International License (http:// creativecommons.org/licenses/by/4.0/), which permits unrestricted use, distribution, and reproduction in any medium, provided you give appropriate credit to the original author(s) and the source, provide a link to the Creative Commons license, and indicate if changes were made.

\section{Literatuur}

1. Oldenburg CS, Berg JM van den, Leikstikow IP. All aboard, getting nationwide indicators on the rails. Collaborative governance as a strategy for developing effective national quality indicators for hospital care. BMJ Outcomes (Inaugural collection). 2015;April.

2. Dutch Institute for clinical auditing. Rapportage 2014. Together we make care count. Leiden: DICA; 2014.

3. Inventarisatie van NICTIZ en het Zorginstituut Nederland. Diemen; 2015.

4. KPMG. Onderzoek kosten kwaliteitsmetingen KPMG Plexus. Utrecht: KPMG; 2015.

drs. Ingrid E.C. van Es senior beleidsadviseur

drs. Sylvia Shackleton-Dijkstra arts, manager Kwaliteit \& Organisatie 